\title{
New species of Polyxenida in Israel (Diplopoda, Penicillata)
}

\author{
M. SHORT \\ Megan Short, Deakin University, 221 Burwood Highway, Burwood, Melbourne, Australia \\ E-mail:megan.short@deakin.edu.au
}

\begin{abstract}
The identification of 5 species from a recent collection of 23 specimens from two areas in Israel is given. Two new species of Polyxenida are recorded, including the first species in the family Synxenidae (Phryssonotus sp.) and the first species from the family Polyxenidae, subfamily Macroxeninae (Chilexenus sp.), from Israel. These species are identified only to genus due to the lack of undamaged adult material. Two species in the family Lophoproctidae are also identified, one previously recorded but not described, is now described as Lophoproctus israelensis $\mathrm{sp}$. nov., and Lophoproctinus chichinii Condé, 1951 is recorded from Israel for the first time. The fifth species is identified as possibly a new species in the genus Polyxenus and likely to be synonymous with the specimens identified as Polyxenus lagurus Linnaeus, 1758 in a previous study. This is just the second collection from Israel to be identified and brings the total number of Polyxenida species found in Israel to 8. All 3 families of Polyxenida are represented in this list, together with all 3 subfamilies of the most numerous family, Polyxenidae.
\end{abstract}

Keywords. Bristly millipedes, biodiversity, Mediterranean, millipedes.

\section{INTRODUCTION}

$\mathrm{I}^{\mathrm{n}}$ the period 1962-1966, Dr G. Levy of The Hebrew University of Jerusalem (Department of Entomology and Venomous Animals) made the first recorded collection of Polyxenida from Israel, with Condé \& Nguyen Duy-Jacquemin (1971) identifying 5 species from this collection, namely Polyxenus lagurus Linnaeus, 1758, Polyxenus chalcidicus Condé \& Nguyen DuyJacquemin, 1971, Propolyxenus trivittatus Verhoeff, 1941 (now a junior synonym of $P$. argentifer (Verhoeff, 1921), see Short et al. (2020)), Miopxenus mootyi Condé, 1951, all in the family Polyxenidae, and one species from the family Lophoproctidae, incompletely identified as Lophoproctus sp.. Polyxenidans have been identified from just 2 neighbouring countries, namely Lophoproctinus chichinii Condé, 1951, from Egypt and Lebanon (Condé 1951, 1954a), Miopxenus mootyi Condé, 1951 from Egypt, and Lophoproctus jeanneli (Brölemann, 1910) from Lebanon (Condé 1954b). In this study, recent collections of polyxenidans from
Israel are identified, including description of a new species.

\section{MATERIALS AND METHODS}

The millipedes examined for this study were collected between 2014-2018 by Amir Weinstein and stored in $75 \%$ ethanol. Selected specimens were measured and then cleared and mounted on slides in Hoyer's medium, and examined with an Olympus Vanox compound microscope. One specimen, not collected, was identified to family from a photograph. Photographs were provided by Amir Weinstein.

\section{RESULTS}

A total of 23 Polyxenida from collection sites in Israel were examined with one new species being described, 2 new species were identified to genus only, but not described due to lack of material, and 2 further species being identified. The geographic distribution of all known localities of the specimens in this study plus 
those reported in Condé \& Nguyen DuyJacquemin (1971) were plotted (Fig. 1). Some additional localities outside Israel were also included.
Abbreviations: ZMUC-Zoological $\mathrm{Mu}-$ seum, University of Copenhagen; HUJ-National Natural History Collections, Hebrew University, Jerusalem, Israel.

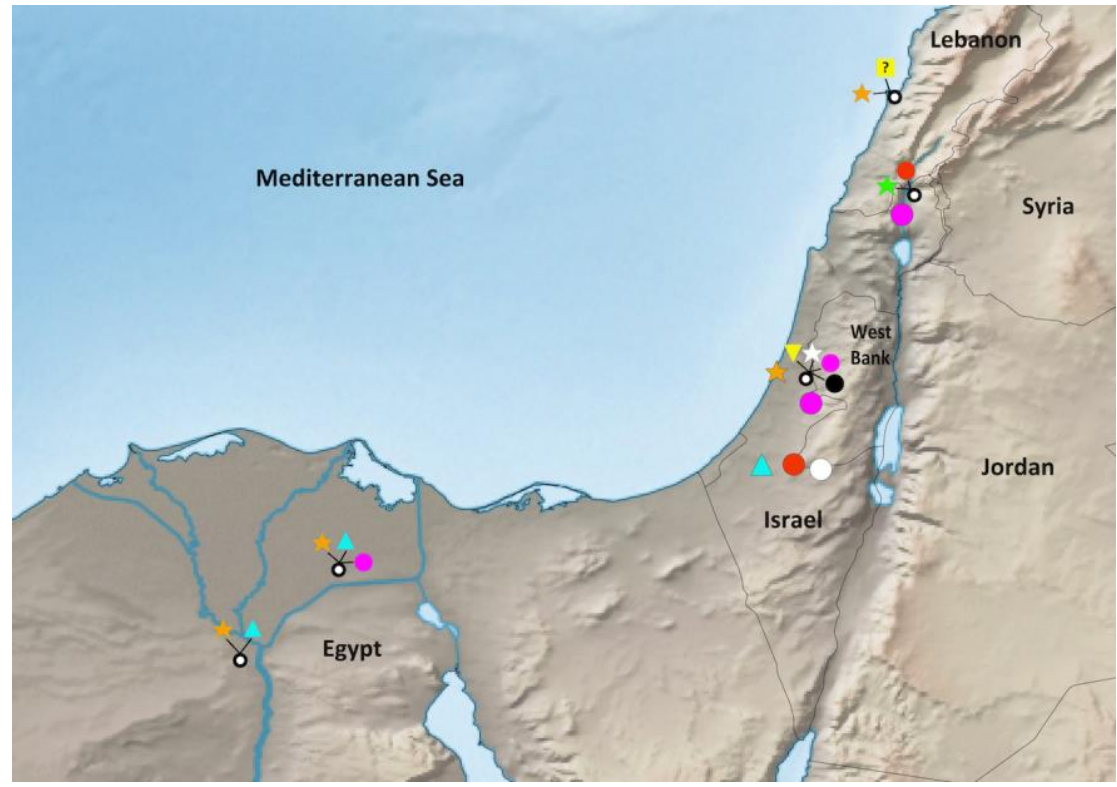

Figure 1. Map showing collection locations of Polyxenida in Israel and neighbouring countries. Legend: purple circle $=$ Polyxenus sp.; red circle $=$ Polyxenus chalcidicus Condé \& Nguyen Duy-Jacquemin, 1971; green star $=$ Propolyxenus argentifer (Verhoeff,

1921); aqua triangle = Miopsxenus mootyi Condé, 1951; inverted yellow triangle = Lophoproctus israelensis sp. nov.; orange star $=$ Lophoproctinus chichinii Condé, 1951; yellow square $=$ Lophoproctus jeanneli $?$ white $\mathrm{star}=$ Phryssonotus sp., black circle $=$ Chilexenus sp., white circle $=$ Lophoproctidae $\mathrm{sp}$

\section{TAXONOMY}

\section{Subclass Penicillata Latreille 1831}

\section{Order Polyxenida Verhoeff, 1934}

\section{Family Lophoproctidae Silvestri, 1897}

\section{Genus Lophoproctus Pocock, 1894} 1894.

Type species. Lophoproctus coecus Pocock,

Diagnosis. Distinguished from other genera of Lophoproctidae, in possessing 4 basiconic sensilla on the $6^{\text {th }}$ antennal article and greater than 4 linguiform processes along the entire anterior rim of the labrum.

\section{Lophoproctus israelensis sp. nov.}

(Figures 1, 2A, 3A-O)

Material examined. Holotype. Adult male (aw-1), Israel, Modi'in area in Judean Hills, near Tel-Hadid, Ben Shemen Forest, N31 ${ }^{\circ} 57^{\prime}$, E3456', 25 Mar. 2016, leg. A. Weinstein. Specimen mounted on slide. Paratypes. One adult male (aw-3), 2 sub-adult females (aw-2, aw-4), same collection as holotype. Specimens mounted on slides. Two adult females (aw-5) same collection as holotype, stored in $80 \%$ ethanol. All material deposited in HUJ. 

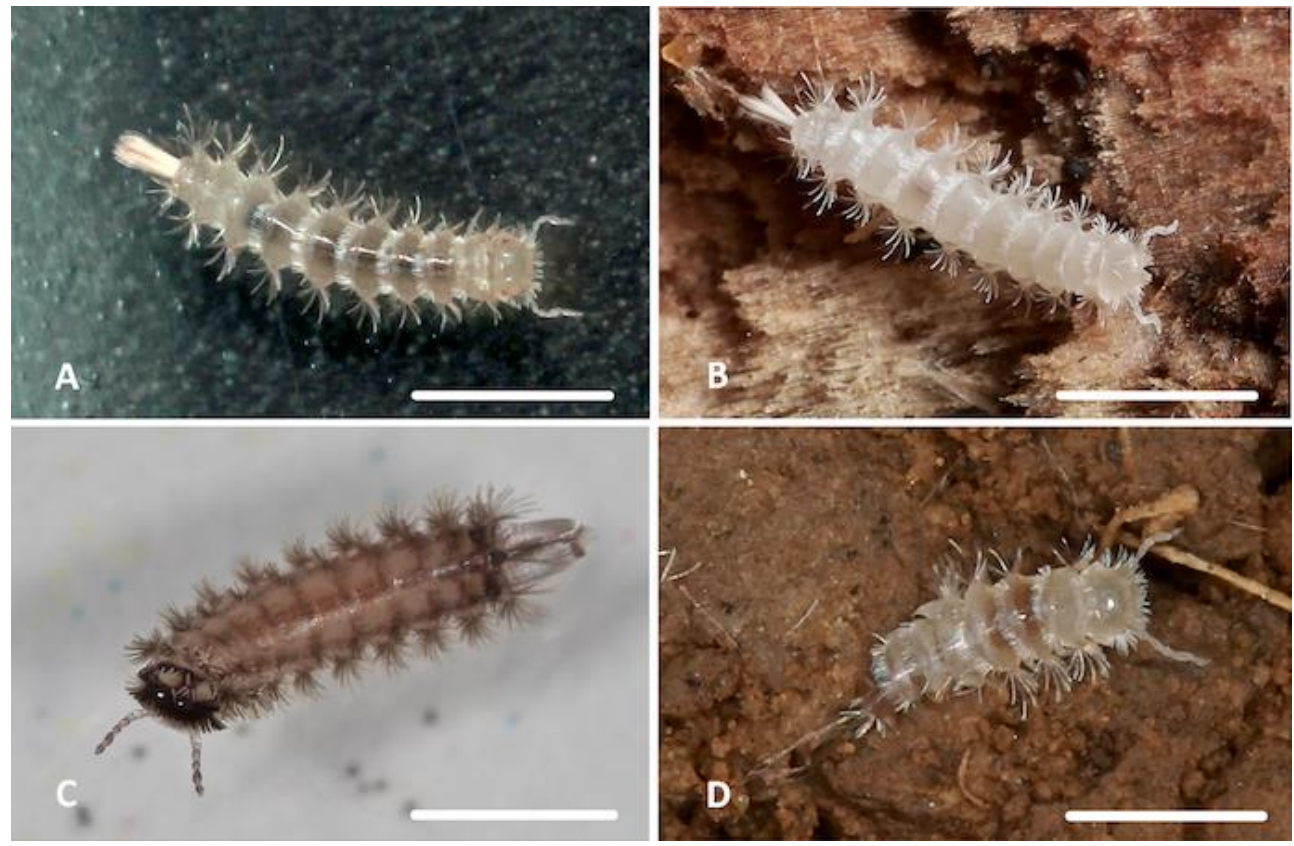

Figure 2. A = Lophoproctus israelensis sp. nov.; B = Lophoproctinus chichinii Condé, 1951; C = Polyxenus sp.; D =

Lophoproctidae sp.. All polyxenidans photographed alive by Amir Weinstein. Used with permission. Scale bars $=1 \mathrm{~mm}$.

Etymology. Adjective, named after the country where it was found.

Diagnosis. Very similar morphology to Lophoproctus jeanneli (Brölemann, 1910), differing in the arrangement of sensilla on the $6^{\text {th }}$ antennal article.

Description. Measurements: Body length without caudal bundle after mounting on slides; holotype: $2.0 \mathrm{~mm}$, tarsus length $13^{\text {th }} \mathrm{leg}, 128 \mu \mathrm{m}$; paratype sub-adult female (aw-2): $2.0 \mathrm{~mm}$, caudal bundle $0.4 \mathrm{~mm}$, tarsus length $13^{\text {th }}$ leg: $117 \mu \mathrm{m}$.

Head (Fig. 3A): Lacking ommatidia. Vertex with 1 pair of posterior tufts each with a single anterior row of 10-12 trichomes, 1 trichome posteriorly, distance between each tuft twice their length, wide gap to anterior vertex trichomes. All trichomes long, slender and barbate. Three trichobothria arranged in an equilateral triangle with the most anterior smaller than the other 2 and with a clavate funicle (Fig. 3H).
Gnathochilarium typical of Lophoproctidae, with a medial palp only. Male holotype with 30 long and 10 smaller biarticulate sensilla (Fig. $3 \mathrm{~J})$, female paratype with 12 long and 8 biarticulate sensilla. Anterior margin of labrum with 11 linguiform processes each side, median pair with pointed apex, rest with parallel sides and a rounded apex. External surface of labrum with folds but lacking any visible ornamentation, 911 setae along posterior margin (Fig. 3K).

Antennae: Long antennae with proportions of antennal articles as in Figure 3G. $6^{\text {th }}$ article a third longer than $7^{\text {th }}$ article, while $7^{\text {th }}$ and $8^{\text {th }}$ articles equal in length. Of note is the unusually elongate $4^{\text {th }}$ article. Details of sensilla based on holotype and sub-adult female paratype. Antennal article VI with 4 long basiconic sensilla arranged in diamond pattern, with a conical sensillum posteriorly (Fig. 3F); antennal article VII with 1 basiconic sensillum to posterior of 1 short basiconic sensilla and 1 posterior coeloconic sensillum (Fig. 3E). 

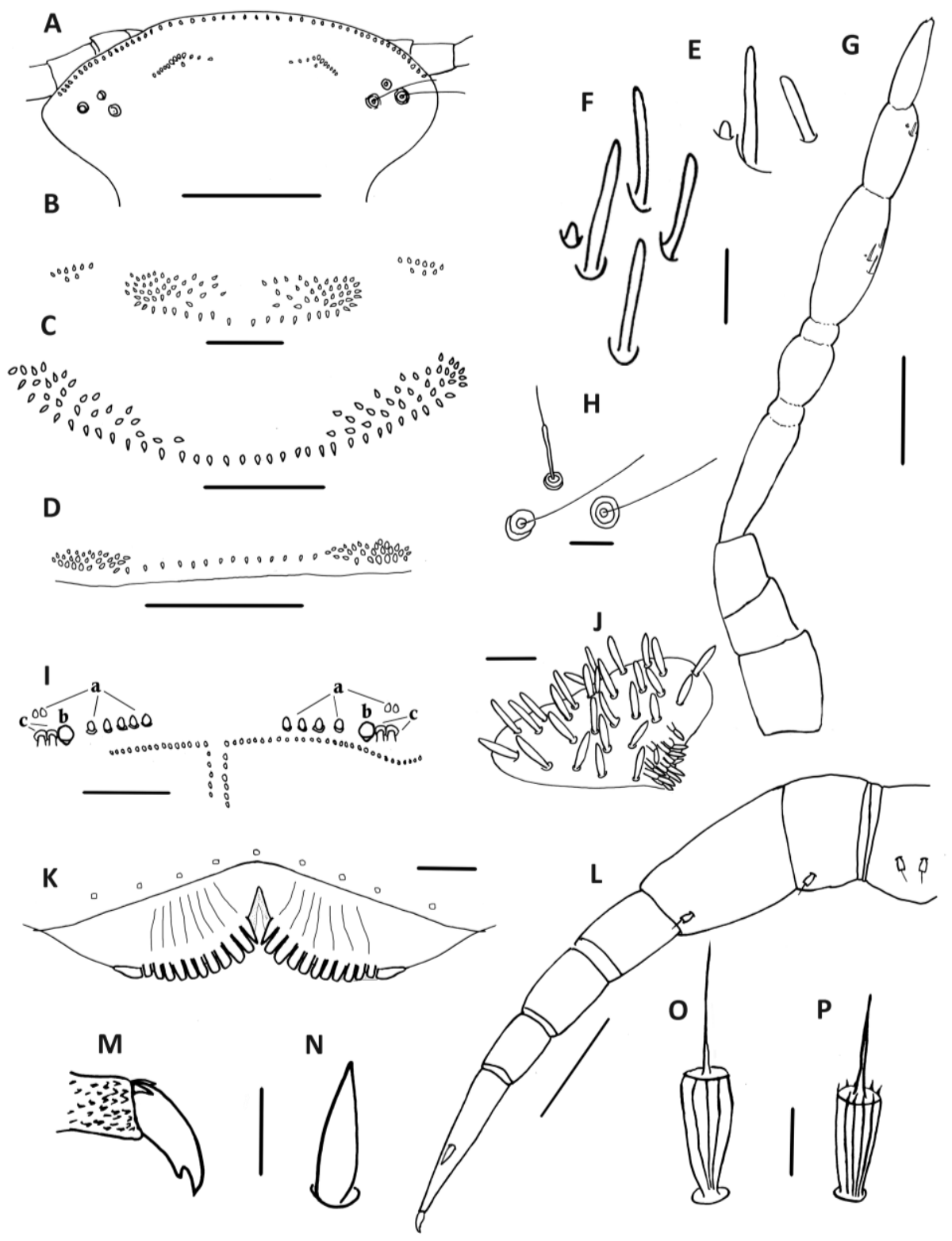

Figure 3. Lophoproctus israelensis sp. nov. (A-O) and Lophoproctinus chichinii Condé, 1951. (P). A = Head; B = Collum showing pattern of insertions of trichomes; $\mathrm{C}=$ Tergite 2 showing pattern of insertions of trichomes; $\mathrm{D}=$ Tergite 10 showing pattern of insertions of trichomes; $\mathrm{E}=$ Pattern of basiconic sensilla on antennal article VII; F = Pattern of basiconic sensilla on antennal article VI; $\mathrm{G}=$ Left antenna; $\mathrm{H}=$ Trichobothria; $\mathrm{I}=$ Pattern of insertions of dorso-medial trichomes, see text for details of $a, b$ and $c ; \mathrm{J}=$ Right gnathochilarium, male; $\mathrm{K}=$ Labrum; $\mathrm{L}=$ Sixth leg, left side; $\mathrm{M}=$ Telotarsus; $\mathrm{N}=$ Tarsal spine; $\mathrm{O}=\mathrm{Seta}$ on femora, pre-femora and coxae. $\mathrm{P}=$ Seta on femora, pre-femora and coxae in Lophoproctinus chichinii Condé, 1951. Scale bars: A, C, G, L =100 $\mu \mathrm{m} ; \mathrm{B}, \mathrm{D}, \mathrm{I}=50 \mu \mathrm{m} ; \mathrm{H}, \mathrm{K}=20 \mu \mathrm{m}$; E and $\mathrm{F}$ (shared bar), J, M and N (shared bar),

$\mathrm{O}$ and $\mathrm{P}($ shared bar $)=10 \mu \mathrm{m}$. 
Trunk: Collum with almost symmetrical arrangement of 86 trichomes (holotype), made up of lateral rosettes either side with $31+29$ trichomes and a posterior row of 26 trichomes facing posteriorly, a small medial gap (Fig. 3B). Lateral protuberances of collum with 8-9 barbate trichomes arranged in two rows (Fig. 3B). Remaining tergites (Figs. 3C, D) with lateral elongate rosettes linked by a continuous posterior row of trichomes. Holotype tergite 2 with 85 trichomes. Trichomes, barbate with serrations not extending to the base, those of posterior row wider than those of the lateral tufts.

Legs (Fig. 3L): Naming of leg segments is after Manton (1956). Legs 1 and 2 without trochanter, leg 1 also lacking tarsus 1 . Trochanter, post-femur and tarsus 1 lacking setae. Prefemora and femora each with 1 seta, coxa 1 with 1 seta, coxae 2-9, 2-3 setae, coxae 10-13, 1 seta, setae biarticulate with 8-10 longitudinal striations along funicle, and a long setiform process distally (Fig. 3O); spine on tarsus 2 slightly longer than claw (Fig. $3 \mathrm{~N}$ ); claw of telotarsus with a denticle and two small processes at base (Fig. $3 \mathrm{M})$.

Telson: Dorso-medial (ornamental) trichomes each side of midline with 4-5 trichomes $\boldsymbol{a}$ internally and 2 smaller trichomes $\boldsymbol{a}$ externally, 1 trichome $\boldsymbol{b}$, and 2 trichomes $\boldsymbol{c}$ in cluster between external and internal trichomes $\boldsymbol{a}$ (Fig. 3I); two bundles of caudal trichomes beneath with a very narrow gap, hooked trichomes of caudal bundles most commonly with 4 hooks.

Habitat. In soil and litter under tree canopy, adjacent to large rocks, in pine forest planted in the mid 1960s.

Remarks. Species in the genus Lophoproctus share a very similar morphology with species identification being based on small differences. Just two species, L. jeanneli and L. israelensis have a denticle associated with the claw. It is for this reason that Condé \& Nguyen Duy-Jacquemin (1971) identified the specimen from Israel that they examined as Lophoproctus "jeanneli group". However, they noted the different pattern of sensilla on the $6^{\text {th }}$ antennal article preventing identification as $L$. jeanneli. The speci- men they examined is now assumed to be $L$. israelensis sp. nov. A further lophoproctid was photographed by collector Amir Weinstein in 2014 (Fig. 2D) under stones in an exposed arid area of the Yatir forest, a planted forest on the southern slopes of Mt Hebron on the edge of the Negrev Desert. Unfortunately, the specimen was not collected but although a photograph suggests it is likely to be $L$. israelensis sp. nov., the species cannot be confirmed until material is examined.

\section{Genus Lophoproctinus Silvestri, 1898}

Type species. Lophoproctinus inferus (Silvestri, 1903) [= Lophoproctus inferus Silvestri, 1903]

Diagnosis. Distinguished from other genera of Lophoproctidae, in possessing 3 basiconic sensilla on the $6^{\text {th }}$ antennal article and greater than 4 linguiform processes along the anterior rim of the labrum.

\section{Lophoproctinus chichinii Condé, 1951}

(Figures 1, 2B, 3P)

Diagnosis. Very similar to Lophoproctinus inferus var. maurus (Marquet et Condé, 1950), but differs in the basiconic sensilla of the $6^{\text {th }}$ antennal article being arranged in a spaced oblique line rather than transversely. Also differs in having a stockier telotarsus.

Material examined. One adult female (aw6), 1 sub-adult female (aw7), whole mounts on slides, 1 sub-adult female in ethanol (aw8), Israel, Bat-Yam, in rotting cypress $\log$ in back garden, $\mathrm{N} 32^{\circ} 0^{\prime}$, E34 $45^{\prime}, 14$ Jan. 2017, leg. A. Weinstein. All material is to be deposited in HUJ.

Remarks. This species was described in Condé (1951) from 2 adult female specimens found in the Nile Valley, Egypt. In a footnote in Condé (1954a), there is brief mention of identification of a sub-adult male $L$. chichinii from Beirut, Lebanon. It is unfortunate that the figures in Condé (1951) lack an illustration of a typical leg seta, as his written description merely indicates that the setae are biarticulate with a subcylindrical, glabrous funicle. The Israeli specimens examined in this 
study have setae with funicles that are not only sub-cylindrical and glabrous but are also distinguished by longitudinal striations extending distally in a series of thin points that surround the base of the flagellum (Fig. 3P). The absence of any mention of these distinctive details is a concern, however it should be noted that in describing Anopsxenus indicus Condé et Jacquemin, 1963, the authors neglected to mention the longitudinal striations that are obviously present in the figure provided in the same paper of a leg seta. In his description, Condé (1954a) described the caudal bundles of the Egyptian specimens of live L. chichinii as light brown, whereas the Israeli specimens have a distinctly white caudal bundle when alive (Fig. 1B).

\section{Family Polyxenidae}

\section{Subfamily Polyxeninae Condé, 2008}

Diagnosis. Structure of the telson with two caudal bundles of trichomes widely separated, with a dorso-medial fan of barbate trichomes.

\section{Genus Polyxenus Latreille, 1802} 1758

Type species. Polyxenus lagurus Linnaeus,

Diagnosis. Tergites with trichomes arranged in rosettes laterally, with 2 evenly spaced transverse rows along posterior edge.

\section{Polyxenus sp.}

(Figures 1, 2C)

Material examined. One adult male (aw9), Israel, Modi'in area in Judean Hills, near TelHadid, Ben Shemen Forest, N31 ${ }^{\circ} 57^{\prime}$, E34 $4^{\circ} 56^{\prime}$, 25 Mar. 2016, leg. A. Weinstein, slide mounted; 5 specimens from same collection in $80 \%$ ethanol (aw10), all deposited HUJ; 1 adult male, Israel (no further details), ex coll. M. Warburg, slide mounted, deposited in ZMUC.

Remarks. Polyxenus sp. specimens have been collected from a number of countries, but although their morphological characters would suggest that they are $P$. lagurus, they can be distinguished by their very small size, sexual mode of reproduction, and their genetic distinctness (Short et al. 2020). Only one of these tiny Polyxenus has been described to date, $P$. lankaranensis Short et al., 2020 (see Short et al. 2020), found in Azerbaijan and Russia. Other genetically distinct small Polyxenus have been collected from Spain, Hungary, Italy and Crimea (Short et al. 2020).

The specimens examined in this study appear morphologically very close to $P$. lankaranensis, with a small size (body length adult male $1.85 \mathrm{~mm}$ ). Medial anterior vertex trichomes are similar to $P$. lankaranensis, being shorter, a darker colour, and more bulbous with shorter serrations than those of $P$. lagurus (Short et al. 2020). However, it will require collection of specimens suitable for gene sequencing to determine if they are a new or an existing species.

It is unfortunate that Condé \& Nguyen DuyJacquemin (1971) did not give the size of specimens they identified from Israel as sexually reproducing populations of Polyxenus lagurus, as it is possible that these might not be $P$. lagurus. The only description given is of the number of thin sensilla on antennal article VI, the numbers of which are not useful for distinguishing $P$. lagurus from $P$. lankaranensis or other Polyxenus species. In Figure 1, both $P$. lagurus and Polyxenus sp. have been mapped simply as Polyxenus sp..

\section{Family Polyxenidae}

\section{Subfamily Macroxeninae Condé, 2008}

Diagnosis. Presence of pseudoarticulated sensilla on the palpi of the gnathochilaria. Type II (Condé 1969) telson with two latero-dorsal bundles of hooked trichomes joined closely side by side; dorsal face of telson with a row of barbate trichomes $\boldsymbol{a}$ each side of median plate, and a cluster of longer barbate trichomes $c$ each side protruding into the bundles of hooked trichomes. 


\section{Genus Chilexenus Silvestri, 1948}

Diagnosis. Spine on tarsus 2. Short distance between oval lateral tufts of trichomes. Three basiconic sensilla on antennal article VI.

Type species. Chilexenus rosendinus Silvestri, 1948.

\section{Chilexenus sp.}

(Figures 1, 4)

Material examined. One female adult (aw11), Israel, Modi'in area in Judean Hills, near Tel-Hadid, Ben Shemen Forest, N31 $57^{\prime}$, E345ㅇ', 25 Mar. 2016, leg. A. Weinstein, slide mounted.

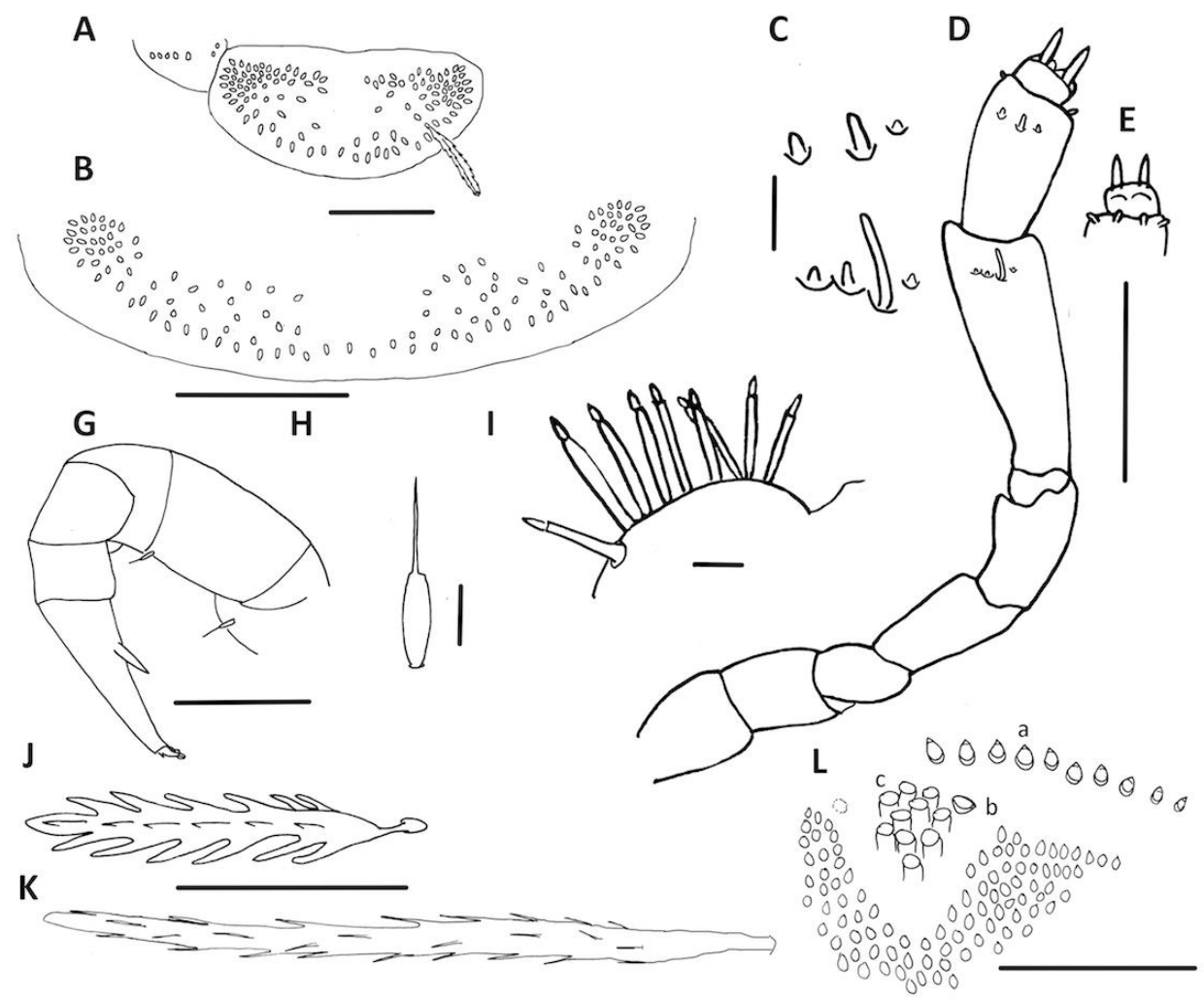

Figure 4. Chilexenus sp. A = Collum showing pattern of trichome insertions; $\mathrm{B}=$ Tergite 2 showing pattern of trichome insertions; $\mathrm{C}=$ Detail of sensilla on 6th and 7 th antennal articles; $\mathrm{D}=$ Right antenna, dorsal view; $\mathrm{E}=$ Right antenna, ventral view of $7^{\text {th }}$ (part) and $8^{\text {th }}$ antennal articles; $\mathrm{G}=$ Part of leg $6 ; \mathrm{H}=$ Seta found on femora and prefemora; $\mathrm{I}=$ Portion of medial palp showing pseudoarticulated sensilla; $\mathrm{J}=$ Typical shape of tergal trichomes of transverse posterior rows; $\mathrm{K}=\mathrm{Barbate}$ trichome of the lateral tergal rosettes; $\mathrm{L}=$ Pattern of dorso-medial trichome insertions (refer text for details of a, b and c). Scale bars: A, B, D and E (shared bar) $=100 \mu \mathrm{m} ; \mathrm{G}, \mathrm{J}$ and $\mathrm{K}$ (shared bar), L = 50 $\mu \mathrm{m} ; \mathrm{C}, \mathrm{H}, \mathrm{I}=10 \mu \mathrm{m}$.

Remarks. Nguyen Duy-Jacquemin (2009) in her revision of the subfamily Macroxeninae provided a key to the genera within the subfamily. The single adult female from Israel possesses characters consistent with the subfamily, namely,
8 ommatidia, a small gap between bundles of caudal trichomes (giving the appearance of a single bundle), pseudoarticulated sensilla on the gnathochilaria (Fig. 4I), and the pattern of dorsomedial trichomes (Fig. 4L). Classification to the 
genus Chilexenus can be made based on the presence of a large tarsal spine (Fig. 4G), 3 basiconic sensilla on antennal article VI (Fig. 4C), and the pattern of tergal trichomes (Figs. 4A and 4B). Comparison with descriptions of $C$. rosendinus (Silvestri 1903, 1905, Nguyen Duy-Jacquemin 2009) indicates that the specimen from Israel is a new species. This specimen is smaller with a body length (without caudal bundle) of $1.95 \mathrm{~mm}$ in comparison with $C$. rosendinus at $2.70 \mathrm{~mm}(\mathrm{Ngu}-$ yen Duy-Jacquemin 2009), and the antennal sensilla are very reduced in size with the exception of the posterior sensillum on article VI. An unusual feature is the presence of 4 distinctive oval structures evenly positioned protruding from the ventro-distal edge of antennal article VI (Fig. 4E). Although these structures are not mentioned in any of the descriptions of $C$. rosendinus, two are shown to be present in Silvestri (1905: plate 36, fig. 38). A further unusual feature of the Israeli specimen is the apparent presence of just two very large apical sensilla on antennal article VIII, when the typical pattern for Polyxenida is four. It will be necessary to collect more specimens of this species in order to determine if the absence of 2 apical sensilla is typical of the species.

It is interesting to note that Chilexenus has a similar disjunct geographic distribution (South America and Mediterranean) to Macroxenus with $C$. rosendinus found in Chile while the new species is from Israel. In the genus Macroxenus, of the two species identified to date, M. rubromarginatus (Lucas, 1846), is found in Portugal, Morocco, Algeria and Malta, and $M$. caingangensis (Schubart, 1944) in Brazil. Of the two remaining genera in the subfamily Macroxeninae, Macroxenodes Silvestri, 1948 is only found in the Americas while Afraustraloxenodes Nguyen Duy-Jacquemin, 2003 has only been identified from southern Africa.

\section{Family Synxenidae}

\section{Genus Phryssonotus}

Diagnosis. This genus is characterised by 17 pairs of legs, 15 normal walking pairs of legs and 2 pairs of pushing legs caudally; 11 tergal plates and a telson; 10 pleural projections; tergites covered medially with scale trichomes directed caudally, long thin barbate trichomes laterally, 8-11 ommatidia; a long frontal trichome A and short frontal trichomes B adjacent to anterior trichobothrium c. Trichobothrium c smaller than other two trichobothria. 1854).

Type species. Phryssonotus hystrix (Menge,

\section{Phryssonotus sp.}

(Figures 1, 5B)

Material examined. One immature only (aw12), Israel, Modi'in area in Judean Hills, near Tel-Hadid, Ben Shemen Forest, N31 $57^{\prime}$, E345', 25 Mar. 2016, leg. A. Weinstein, slide mounted, deposited in the National Natural History Collections in the Hebrew University of Jerusalem, Israel.

Remarks. The single specimen collected is not only an immature stadium, but also damaged, lacking almost all trichomes including the scale-like dorsal trichomes so distinctive of the genus. However, the two characteristics Silvestri (1923) used to distinguish species of Phryssonotus: number of ommatidia and number of short frontal trichomes B are visible. In their paper redescribing $P$. novaehollandiae (Silvestri, 1923), Short \& Huynh (2006) noted that the number of trichomes B increases with each molt until the adult stadium, whereas the number of ommatidia is unchanged from stadium V1. The immature (stadium VI) Phryssonotus sp. in this study has 9 ommatidia and 2 trichomes B (Fig. $5 \mathrm{~B})$ indicating that the adult characters are most likely to be 9 ommatidia and $>2$ trichomes B. As adult $P$. platycephalus (Lucas, 1846), the only species described to date from the northern hemisphere (Silvestri 1923), has 11 ommatidia and only 1 trichome B (Fig. 5A), it appears that the Phryssonotus specimen from Israel is a new species.

$P$. platycephalus has a Mediterranean distribution, having been collected in Algeria, eastern Libya, Spain, Sicily, and in the Balearic Islands. The first very brief description of the species by Lucas (1846) with figures in Lucas (1849) used uninformative characters, such that the more detailed redescription by Silvestri (1948) from 


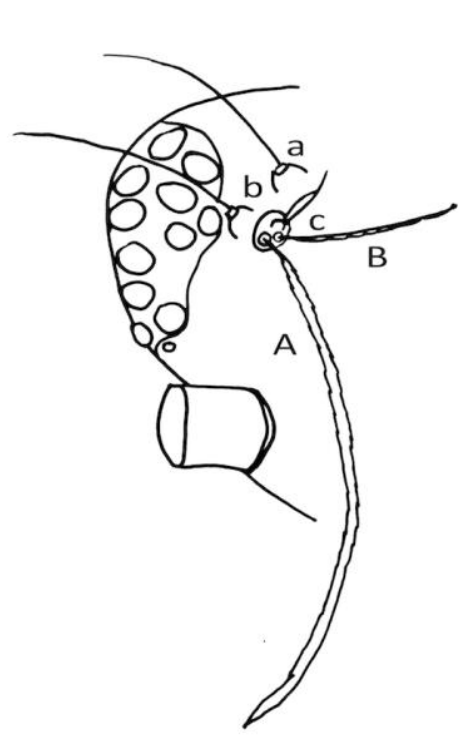

A

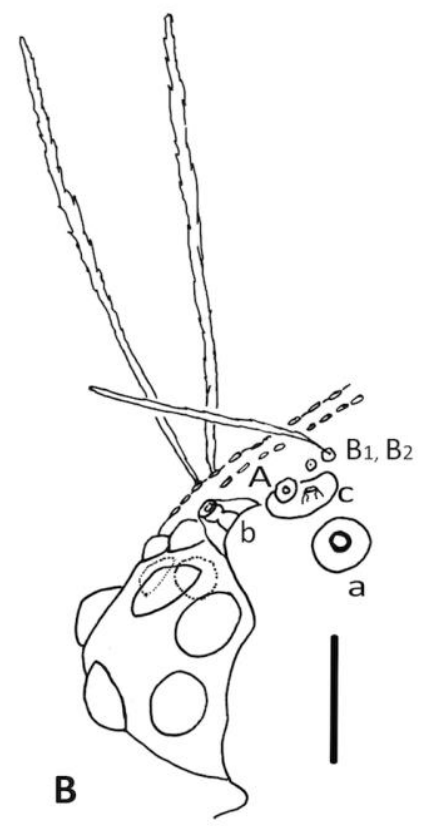

Figure 5. A = Phryssonotus platycephalus (Silvestri, 1923), ventral view of the right side of head redrawn from Silvestri (1923) showing characters used in the original description; B = Phryssonotus sp., Immature, stadium VI, dorsal view of left side of head showing the same characters. Diagnostic characters illustrated are: trichobothria a, b and c, long frontal trichome A, and short frontal trichomes B, B1, B2. No scale was given in the original drawing, scale bar for Figure 5B $=100 \mu \mathrm{m}$.

specimens collected in Spain is now used to identify and define the species. It is possible that the type from Algeria differs from the Phryssonotus from Spain, and synxenids from other countries identified from Silvestri's description may in fact not be $P$. platycephalus. This will be a problem until such time as the types from $\mathrm{Al}-$ geria are found and re-examined, or a new collection is made from the type locality. As well, detailed examination of specimens from other populations needs to be made.

\section{DISCUSSION}

Eight species have now been identified, if not all fully described as yet, from Israel (Tab. 1). Quite remarkable is not only the number of species from the northern half of such a tiny country, collected by just two individuals, but also the diversity, with all 3 families of Polyxenida (Polyxenidae, Synxenidae and Lophoproctidae) represented, as well as all 3 subfamilies of the largest family Polyxenidae. Such a concentrated diversity of Polyxenida has yet to be found elsewhere worldwide. It can only be speculated as to the reasons for this diversity. Is it possibly due to Israel being at the intersection of the African and European continents, with a Mediterranean climate to the north and a drier desert to the south? Polyxenidans have been found in arboreal birds' nests (Nguyen Duy \& Condé 1966, Tajovský et al. 2001) and in elevated habitats such as tree canopies, so it is possible that they are transported by wind and attached to birds' feathers by their hooked setae. Aerial dispersal is supported by unpublished data from three different investigations in the Harz Mountains National Park, Germany, with $P$. lagurus being found in air traps as well as in color traps (Lindner pers. comm. 2020). So, might the bird migration flight paths or direction of winds across Israel also be factors contributing to polyxenidan diversity? 
Table 1. List of Polyxenida identified from Israel.

\begin{tabular}{|c|c|c|c|}
\hline Family & Subfamily & Species & $\begin{array}{l}\text { Records of presence in } \\
\text { Israel }\end{array}$ \\
\hline Synxenidae & & Phryssonotus sp. & Current study \\
\hline \multirow[t]{5}{*}{ Polyxenidae } & Polyxeninae & $\begin{array}{l}\text { Polyxenus sp. (formerly identified as } \\
\text { Polyxenus lagurus, Linn., 1758). }\end{array}$ & $\begin{array}{l}\text { Condé \& Nguyen Duy- } \\
\text { Jacquemin 1971, } \\
\text { current study }\end{array}$ \\
\hline & & $\begin{array}{l}\text { Polyxenus chalcidicus Condé \& } \\
\text { Nguyen Duy-Jacquemin, } 1971\end{array}$ & $\begin{array}{l}\text { Condé \& Nguyen Duy- } \\
\text { Jacquemin } 1971\end{array}$ \\
\hline & & $\begin{array}{l}\text { Propolyxenus argentifer (Verhoeff, } \\
\text { 1921), (= Propolyxenus trivittatus } \\
\text { Verhoeff, 1941) }\end{array}$ & $\begin{array}{l}\text { Condé \& Nguyen Duy- } \\
\text { Jacquemin } 1971\end{array}$ \\
\hline & Monographinae & Miopxenus mootyi Condé, 1951 & $\begin{array}{l}\text { Condé \& Nguyen Duy- } \\
\text { Jacquemin } 1971\end{array}$ \\
\hline & Macroxeninae & Chilexenus sp. & current study \\
\hline \multirow[t]{2}{*}{ Lophoproctidae } & & Lophoproctus israelensis sp. $\mathrm{n}$. & $\begin{array}{l}\text { Condé \& Nguyen Duy- } \\
\text { Jacquemin 1971, } \\
\text { current study }\end{array}$ \\
\hline & & Lophoproctinus chichinii Condé, 1951 & current study \\
\hline
\end{tabular}

Acknowledgements - The dedication of Amir Weinstein to collection of the smaller invertebrates, such as Polyxenida, is much to be commended, as is his photography. Thanks to Nesrine Akkari for chasing up the illusive figures from Silvestri (1905). Sergei Golovatch (Moscow, Russia) and László Dányi (Budapest, Hungary) kindly edited the text of an advanced draft.

\section{REFERENCES}

BrölemanN, H.W. (1910): Biospeologica. XVII. Symphyles, Pselaphognathes, Polydesmoides et Lysiopetaloides (Myriapodes) (première série). Archives de Zoologie expérimentale et générale, 5e série, 5(7): 339-378.

Conde, B. (1951): Pénicillates de Basse-Egypte (Myriapodes Diplopodes). Bulletin de la Société zoologique de France, 76: 55-63.

CONDE, B. (1954a): Diplopodes pénicillates d'afrique septentrionale.Bulletin du Muséum, 2 série, 26(4): 496-500.

CondE, B. (1954b): Sur la faune endogée de Majorque (Penicillates, Protures, Diploures Campodéidés, Palpigrades). Bulletin du Muséum national d'Histoire naturelle, 2e série, 26: 674 677.

CondE, B. (1969): Essai sur l'évolution des diplopodes pénicillates. Bulletin $d u$ Muséum national d'Histoire naturelle, 2e série, 41(Supplément 2): 48-52.

Conde, B. \& Jacquemin, M. (1963): Diplopodes Pénicilates récoltés à Bombay par P.A. Remy. Revue française d'Entomologie, 30: 68-76.

Conde, B. \& NGuYen DuY-JACQuemin, M. (1971): Pénicillates d'Israël rassemblés par G. Levy. Bulletin du Muséum national d'Histoire naturelle, 2e série 42(6): 1251-1258.

CONDE, B. \& NGUYEN DUY-JACQUEMIN, M. (2008): Classification actuelle des diplopodes pénicillates (Myriapodes) avec nouvelles definitions des taxa. Bulletin de la Société zoologique de France, 133(4): 291-302.

LuCAS, M.H. (1840): Histoire Naturelle des Crustacés, des Arachnides et des Myriapodes. P. Duménil, Paris, $600 \mathrm{pp}$.

LuCAS, M.H. (1846): Notes sur quelques nouvelles espèces d'insectes qui habitent les possessions 
françaises du nord de l'Afrique: Myriapodes. Revue zoologique, par la Société Cuvierienne, 9: 283-289.

LUCAS, M.H. (1849): Histoire naturelle des animaux articulés. Exploration scientifique de l'Algérie pendant les années 1840, 1841, 1842. Sciences Physiques, Zoologie 1: Crustacées, Arachnides, Myriapodes. Atlas. Imprimérie Impériale, Paris, pp. 322-390.

MANTON, S.M. (1956): The Evolution of Arthropodan Locomotory Mechanisms - Part 5: The Structure, Habits and Evolution of the Pselaphognatha (Diplopoda). Journal of the Linnean Society London, 43: 153-187. doi: 10.1111/j.1096-3642.1957.tb02516.x

MARquet, M.L. \& CONDE, B. (1950): Contribution à la connaissance des Diplopodes Pénicillates d'Afrique et de la région madécasse. Mémoires de l'Institut Scientifique de Madagascar, série A, 4(1): 113-134.

NGuYen DuY-JacQuemin, M. (2003): A new genus of Penicillata from Southern Africa with pseudoarticulated sensilla on the palpi of the gnathochilarium (Diplopoda: Polyxenida: Polyxenidae). African Invertebrates, 44(1) 71-87.

NGUYen DuY-JACQUEMIN, M. (2009): Revision of the genera of Polyxenidae bearing pseudoarticulated gnathochilarial sensilla (Diplopoda, Polyxenida, Polyxenidae), with the description of two new species. Zoosystema, 31(4): 829-848. doi: $10.5252 / \mathrm{z} 2009 \mathrm{n} 4 \mathrm{a} 5$

Nguyen Duy-Jacquemin, M. \& Conde, B. (1966): Pénicillates nidicoles de Malaisie. Review. Revue d'Ecologie et de Biologie du Sol, 3(4): 621-624.

SCHUBART (1944): Los Diplopodos de Pirassununga. Acta Zoologica Lilloana, 2: 321-440.

SHORT, M. \& HuYNH, C. (2006): Redescription of Phryssonotus novaehollandiae (Silvestri, 1923) withdetails of post-embryonic stadia. Norwegian Journal of Entomology, 53(2): 211-222.
Short, M., VAhtera, V., Wesener, T. \& Golovatch, S.I. (2020): The millipede family Polyxenidae (Diplopoda, Polyxenida) in the faunas of the Crimean Peninsula and Caucasus, with notes on some other Polyxenidae. Zootaxa, 4772(2): 306-332. doi: 10.11646/zootaxa.4772.2.4

Silvestri, F. (1903): Note diplopodologiche. Bollettino del Musei di Zoologia e di Anatomia comparata della Reale Università di Torino, 18(433): 1-21. doi: 10.5962/bhl.part.26628

Silvestri, F. (1905): Fauna Chilensis, Myriapoda. Zoologische Jahrbücher. Abteilung für Systematik, (suppl.), 6(3): 715-772.

Silvestri, F. (1923): Notizia della presenza del genere Synxenus (Myriapoda Diplopoda) in Catalogna e descrizione di quattro specie. Treballs del Museu de Ciències Naturals de Barcelona, 4(5): 5-15.

SILVESTRI, F. (1948): Tavola sinottica dei generi dei Diplopoda Penicillata. Bollettino del Laboratorio di entomologia agraria "Filippo Silvestri", 8: 214-220.

TAJovsky, K., Mock, A. \& KRUMPÁL, M. (2001): Millipedes (Diplopoda) in birds' nests. European Journal of Soil Biology, 37: 321-323. doi: 10.1016/S1164-5563(01)01108-6

VERHOEFF, K.W. (1921): Über Diplopoden der Riviera und einige alpenländische Chilognathen (92. Diplopoden-Aufsatz). Archiv für Naturgeschichte, 87A(2): 1-110.

VERHOEFF, K.W. (1941): Asyanin zoogeografiyasi ve hayvan sistematige hakkinda. Asiatische Beiträge V., VI. Istanbul Üniversitesifen Fakültesi Mecmuasi, Seri B, 6(3-4): 277-318. 